\title{
COMORBIDITY BETWEEN PSYCHOLOGICAL DISTRESS AND DRUG USE AMONG PATIENTS IN TREATMENT CENTRES IN JAMAICA: IMPLICATIONS FOR POLICIES AND PROGRAMME DESIGN
}

\author{
Patrice Reid ${ }^{1}$, Robert Mann'ㄹ, Carol Strike ${ }^{3}$,Bruna Brands ${ }^{4}$, Akwatu Khenti $^{5}$
}

\footnotetext{
${ }^{1}$ MSc. Investigator. Department of Sociology. Psychology and Social Work. University of the West Indies. Mona Campus. Jamaica. E-mail: patrice.a.reid@gmail.com

2 Ph.D. Investigator. Centre for Addiction and Mental Health. University of Toronto. Toronto, Canada. E-mail: robert_mann@ camh.net

${ }^{3}$ Ph.D. Investigator. Health Systems Research and Consulting Unit. Centre for Addiction and Mental Health. University of Toronto. Toronto, Canada. E-mail: carol_strike@camh.net

${ }^{4}$ Ph.D. Investigator. Office of Research and Surveillance. Drug Strategy and Controlled Substances Programme. Health Canada and Public Health and Regulatory Policies. Center for Addiction and Mental Health. University of Toronto. Toronto, Canada. bruna_brands@camh.net

${ }^{5}$ MSc. Director International Health Office. Centre for Addiction and Mental Health. Toronto, Canada. E-mail: akwatu_khenti@ camh.net
}

ABSTRACT: This research explored comorbidity between psychological distress and drug use among patients in treatment centres in Jamaica and the possible implications for policy and programme design for treatment centres. The study was cross-sectional and consisted of 56 adult patients of Jamaican nationality, ages 18 to 70 years old being treated in centres for substance use across three parishes. Patients completed a questionnaire consisting of an adapted version of the EULAC-CICAD Admission form; the Kessler Intrument-10; and the Family APGAR scale. Results indicate that $10.7 \%$ of the patients were categorized to have severe psychological distress; $32.1 \%$ categorized with severe psychological distress. Across the general sample $66.1 \%$ have high perceived family functioning, $16.1 \%$ perceive moderate family dysfunction and $17.9 \%$ perceive severe family dysfunction. The predominant treatment received across the centres was counseling $83.9 \%$ and $83.9 \%$ of patients reported being satisfied with their treatment. Overall, results may serve as a stepping stone to larger work to be done in the area; so as to capture a better picture of the phenomena as it exists in Jamaica.

DESCRIPTORS: Comorbidity. Substance use-related disorders. Psychological distress. Mental health assistance.

\section{LA COMORBILIDAD ENTRE LOS TRASTORNOS PSICOLÓGICOS Y EL USO DE DROGAS ENTRE LOS PACIENTES EN CENTROS DE TRATAMIENTO EN JAMAICA: IMPLICACIONES PARA LAS POLÍTICAS Y DISEÑO DEL PROGRAMA}

RESUMEN: Esta investigación explora la comorbilidad entre los trastornos psicológicos y el uso de drogas entre los pacientes en centros de tratamiento en Jamaica y las posibles implicaciones para la política y el diseño del programa para los centros de tratamiento. El estudio fue de corte transversal y consistió en 56 pacientes adultos de nacionalidad jamaicana, de 18 a 70 años de edad atendidos en los centros de consumo de sustancias a través de tres parroquias. Los participantes completaron un cuestionario que consta de una versión adaptada de la forma de admisión de la EUALC-CICAD; el intrumento-10 Kessler; y la escala de Apgar-familiar. Los resultados indican que el $10.7 \%$ de los pacientes fueron clasificados de tener problemas psicológicos muy graves, el $32.1 \%$ categorizados con graves dificultades psicológicas. $66.1 \%$ tienen un alto funcionamiento familiar percibida, el 16.1\% percibe que la disfunción familiar moderada y el 17.9\% percibe que la disfunción familiar severa. El tratamiento predominante recibidos a través de los centros de asesoramiento fue $83.9 \%$ y el 83.9\% de los pacientes informaron estar satisfechos con su tratamiento. En general, los resultados pueden servir como un trampolín hacia un trabajo más grande que se realiza en la zona, con el fin de capturar una imagen más clara de los fenómenos tal como existe en Jamaica. DESCRIPTORES: Comorbilidad. Trastornos relacionados con sustancias. Distrés psicológico. Atención en salud mental.

\section{COMORBIDADE ENTRE SOFRIMENTO PSÍQUICO E USO DE DROGAS ENTRE PACIENTES EM CENTROS DE TRATAMENTO NA JAMAICA: IMPLICAÇÕES PARA POLÍTICAS E DESENHO DE PROGRAMAS}

\begin{abstract}
RESUMO: Esta pesquisa explorou a co-morbidade entre sofrimento psíquico e uso de drogas entre os pacientes em centros de tratamento na Jamaica e as possíveis implicações para a política e concepção de programas para os centros de tratamento. O estudo foi transversal e consistiu de 56 pacientes adultos, de nacionalidade jamaicana, com idades entre 18 a 70 anos sendo tratados em centros para o uso da substância em três unidades. Os participantes responderam a um questionário composto por uma versão adaptada do formulário de admissão UEALC-CICAD, o Intrumento Kessler-10; e a escala de APGAR familiar. Os resultados indicam que 10,7\% dos pacientes tem grave sofrimento psicológico; $32,1 \%$ com sofrimento psíquico grave. Na amostra geral $66,1 \%$ têm funcionamento familiar elevado, $16,1 \%$ percebem a disfunção familiar moderada e $17,9 \%$ percebem a disfunção familiar grave. O tratamento recebido predominante entre os centros de aconselhamento foi $83,9 \%$ e também $83,9 \%$ dos pacientes relataram estar satisfeitos com seu tratamento. Globalmente, os resultados podem servir como um suporte para maior investimento de trabalho na área, assim como para capturar uma imagem melhor dos fenômenos, uma vez que existe na Jamaica.
\end{abstract}

DESCRITORES: Comorbidade. Sofrimento psíquico. Transtornos relacionados ao uso de substancias. Assistência em saúde mental.

Texto Contexto Enferm, Florianópolis, 2012; 21 (Esp): 133-40. 


\section{INTRODUCTION}

The current research represents one arm of the multi-centric study exploring "Psychological Distress Among Patients in Substance Abuse Treatment Centres in Seven Countries of Latin America and one in the Caribbean: Policy and Program Implications", where the focus of this paper sought to explore the Jamaican reality. Jamaica, one of many islands within the Caribbean region is considered the first producer of Cannabis Sativa and like other islands within the region; its geographic location has made it a trans-shipment point for cocaine from South America to North America and Europe. ${ }^{1}$ In light of this phenomenon, the Jamaican government has established legislation on drug manufacturing, illegal commercialization of drugs, drug control and trafficking. Such legislature includes the Dangerous Drugs Act and Regulation-1948; the Food and Drugs Act-1964, 1966; The Pharmacy Act, 1964; the Food and Drugs Regulation-1975, Precursor Chemical Act-1999, and the Maritime Drug Trafficking Suppression Act which was created in 1998. However, in addition to and due to the phenomenon of drug trafficking, this has fostered the use of drugs. Cites a country's route for drug trafficking as a risk factor for drug abuse. ${ }^{2}$ Hence it is not surprising that Jamaica's society is riddled with problems related to drug misuse and abuse. This phenomenon has fostered the development of the National Council on Drug Abuse (NCDA) in 1983 and related acts. Since the establishment of the NCDA, it acts as the overarching statutory body alongside the Ministry of Health coordinating Jamaica's drug demand reduction initiatives as well as facilitated projects dedicated to prevention and treatment of substance use problems (Multilateral Evaluation Mechanism). ${ }^{3-5}$ The NCDA has agreements and supports a number of officially-licensed specialized treatment and rehabilitation centres across the island which has fostered information on trends related to substance use, misuse and abuse as well as treatment of these problems. Of such trends, the co-occurrence or comorbidity of substance use problems and other psychological problems have been and continue to be noted.

Jamaica is one of few islands within the Caribbean where surveys conducted have accounted for such co-morbid conditions among adolescents and adults citing significant implications for treatment and rehabilitation of substance abusers and otherwise. ${ }^{6-10}$ The NCDA ${ }^{5}$ reported that within six residential treatment and re-habilitation centres, there was a total of 1,594 admissions (ages 10 years and older) between 2004 and 2008. The NCDA ${ }^{5}$ also reported that between the aforementioned period the drugs that elicit the major demand for treatment of abuse/dependence were: crack, marijuana, alcohol, seasoned spliff (this refers to marijuana mixed with cocaine which is smoked), and cocaine. The highest incidence of use of drugs between 2006 and 2009 is that of marijuana and crack. ${ }^{4}$ In presentation to Organization of American States (OAS) and Inter-American Drug Abuse Control Commission (CICAD) on dual diagnosis, stated that according to the National Comorbidity Survey ${ }^{2} 60 \%$ of males and over 70 $\%$ of female alcohol abusers were found to have least one psychiatric disorder in their lives. ${ }^{9}$ Also cited the Epidemiological Catchment Area Survey (1980s) which stated that $45 \%$ of alcoholics and $72 \%$ of illicit drug users had another psychiatric disorder. ${ }^{9}$ The 2001 National Household Survey on Drug Abuse reported that $20 \%$ of the seriously mentally ill were dependent on or abusing alcohol and drugs. In Jamaica, such dual disorders cases are mostly "common among the homeless, prisoners and mental hospital patients".

Furthermore, in study exploring the demographic characteristic pattern of substance misuse and co-morbid axis one disorders found that of 158 clients with a history of substance misuse $31.6 \%$ had a co-morbid psychiatric disorder. ${ }^{9}$ Given the aforementioned one may assume that drug addiction may be compounded by the psychological disorder or vice-versa, which inherently may have further implications for relapse. It is upon this premise that the comorbidity between substance use disorders and other psychological conditions continues to be of interest to stakeholders who are directly involved in the treatment and rehabilitation process. Unlike our North American, European and Australian counterparts where extensive study and documentation of the clinical relevance of mental disorders among people with addiction is well known and established, ${ }^{11-15}$ Jamaica and likewise the rest of the Caribbean have yet to propagate such extensive work, but recognize the need for further research and associated developments. This recognition serves to foster and establish more local based research in addictions and co-morbid mental conditions which have significant implications for the individual's treatment and rehabilitation, familial interactions and overall functioning within their community.

Therefore, this research sought to assess: 1) the prevalence of psychological distress among 
patients who are receiving care in treatment centres for substance abuse/dependence; 2) perceived family functionality among patients with psychological distress; and 3) the attention given to patients receiving care in treatment centres for substance abuse. Answers to these questions were sought in order to possibly influence policy and/ or intervention.

Given that the direction of policy and interventions used within the drug demand, reduction and treatment arena is evidence based, as it is practiced that target goals of policy must be reflective of and congruent with the needs of the population it is geared towards. It is upon this underlying notion that the aforementioned was undertaken.

\section{METHODOLOGY}

Prior to conducting the study, ethical approval was sought and granted from the Research Ethics Office Centre for Addiction and Mental Health in Canada (CAMH) Protocol Reference\# 225/2008, and by the UHWI UWI FMS Ethics Committee at University of The West Indies Mona, Kingston, Jamaica. Upon gaining ethical approval, the NCDA and treatment centres were approached to gain access to treatment facilities to collect data. Meetings were held with respective managers regarding the study and requirements. Upon gaining access to the facilities both staff and clients were oriented to the study. Clients who stated their interest to participate in the study were asked to voluntarily give their informed consent to participate. Clients with mental impairment, intoxication, those treated on psychiatric wards and who refused to give informed consent were excluded from this study.

The study in Jamaica consisted of 49 males and seven females $(n=56)$ of Jamaican nationality, ages 18 to 70 years old (mean age $=39.39$ ), under treatment for substance abuse or dependence in residential $55.4 \%$, detoxification $41.1 \%$ and homeless $3.6 \%$ centres. These centres were located within the Parishes and corresponding cities of St. Andrew-Kingston, St. Ann - Saint Ann's Bay, and Portland-Port Antonio. All participants completed a self-report questionnaire consisting of the: 1) EULAC-CICAD admission form adapted for this study, consisting of 30 questions regarding sociodemographic status, history of drugs and alcohol abuse, judicial history, past and current mental problems and some aspects about the treatment centre; 2) The Kessler Intrument-10 (K-10), a ten-item questionnaire that measures mental/ psychological distress from a symptom-oriented screening perspective. ${ }^{16}$

The classification for psychological distress was made in four groups: low (10-15), moderate (16-21), severe (22-29) and very severe (30-50). For analytical purposes, the majority of studies grouped the two latter categories (severe and very severe distress); and 3) the Family APGAR scale, ${ }^{17}$ is a five item measure of perceived family functionality along the dimensions of adaptability, partnership, growth, affection and resolve, with values for items ranging from zero to two to which one may obtain a minimum score of two and a maximum score of 10 . A total score of seven or more suggests a perception of high family functioning, scores between four and six suggests moderate perceived family dysfunction, and scores of three or less, are indicative of severe perceived family dysfunction. Data collected were entered into and analyzed using the Statistical Package for the Social Sciences (SPSS) version 12.0 by the primary researcher. Analysis of the data due to the small sample size included only descriptive frequencies, cross tabulations and thematic analysis of qualitative responses.

\section{RESULTS \& DISCUSSION}

Results indicated that participants were mainly of Jamaican nationality $(98.2 \%)$ and of Afro-Jamaican descent (67.9\%). The majority of the sample was enrolled in private treatment centres $(55.4 \%)$, with the remaining in public/ governmental based centres (44.6\%). The majority of patients indicated that they sought treatment due to encouragement from friends and family (37.5\%), with the second main reason for having sought treatment was voluntary/self referral $(30.4 \%)$. Other reasons indicated were referrals from employers $(7.1 \%)$, referral from another treatment centre (5.4\%), and referral from the justice system or police department $(5.4 \%)$, referrals from primary $(3.6 \%)$ and tertiary $(3.6 \%)$ health care centres and through announcements made on the radio $(1.8 \%)$. Given this distribution, it would appear that patients who sought treatments are both extrinsically and intrinsically motivated which may have positive implications for remaining in treatment. ${ }^{18-22}$ The drug for which patients sought treatment varied. However, the use of marijuana appeared to be the most consistent problem. The first main substances for which the majority of patients where seeking treatment for was marijuana $(30.4 \%)$ and a combination of crack/cocaine $(28.6 \%)$ (see Table 1 for first main drugs for seeking 
treatment). These trends are consistent with information the national survey obtained from 2004 to 2008, where the major drugs of impact declared by patients admitted to treatment and rehabilitation centres were crack $(n=845)$, marijuana $(n=732)$, alcohol $(n=201)$, seasoned spliff $(n=45)$, cocaine $(n=33)$ and cigarettes/tobacco $(n=13){ }^{5}$

Table 1 - First, second and third main substances for which patients sought treatment in the centres for which they are currently receiving treatment for substance use/abuse in Jamaica, 2010

\begin{tabular}{llrr}
\hline $\begin{array}{l}\text { Order of priority } \\
\text { substances }\end{array}$ & $\begin{array}{l}\text { Licit and } \\
\text { illicit substances/ } \\
\text { drugs }\end{array}$ & $\mathbf{n}$ & $\mathbf{\%}$ \\
\hline & Alcohol & 9 & 16.1 \\
& Marijuana & 17 & 30.4 \\
First substance/drug & Crack & 4 & 7.1 \\
& Cocaine & 9 & 16.1 \\
& Other prescribed & 1 & 1.8 \\
& medications & 16 & 28.6 \\
\hline Total & Crack/cocaine & 10 \\
\hline
\end{tabular}

Among the sample of patients in centres catering to substance use and abuse, it was found that a number of patients reported to have been diagnosed previously with a disorder by a health professional. Specifically, $8.9 \%$ reported being diagnosed with anxiety; $25.0 \%$ with depression, $8.9 \%$ with schizophrenia, and $8.9 \%$ with bipolar disorder. Other diagnoses included single reported incidences of Attention Deficit Hyperactivity Disorder (ADHD), Borderline Personality Disorder (BPD), seizure, delusional/hallucination, and psychosis (see Table 4). Among the patients with these reported disorders $5.4 \%$ who reported being diagnosed with anxiety were being treated for it and within the treatment centre; $19.6 \%$ diagnosed with depression were being treated and within the centres; $7.1 \%$ diagnosed with schizophrenia were being treated and within the centres; $7.1 \%$ diagnosed with bipolar were being treated and within the centres and 1.8\% who reported being diagnosed with other disorder was being treated within the centres. Given that individuals who suffer from substance addiction may have one or more accompanying mental disorder and/or medical issue, ${ }^{23}$ it is essential that treatment centres seek to address both problems as drugs of abuse can cause abusers to experience symptoms of mental illness and on the converse, mental illness can also lead to drug abuse. ${ }^{24}$ Additionally, various studies have found that the severity of substance use and psychiatric problems are reliable predictors of drop out and poorer follow-up outcomes..$^{25}$ Hence, it is imperative for the treatment centres to address both conditions of substance abuse and other mental illnesses.

Table 2 - History of mental health problems - Previous diagnosis from a mental health professional among patients in centres treating substance use and abuse, Jamaica, 2010

\begin{tabular}{lccc}
\hline Diagnosed disorder & $\begin{array}{c}\text { Yes } \\
\mathbf{n}(\%)\end{array}$ & $\begin{array}{c}\text { No } \\
\mathbf{n}(\%)\end{array}$ & $\begin{array}{c}\text { No } \\
\text { response } \\
\mathbf{n}(\%)\end{array}$ \\
\hline Anxiety & $5(8.9)$ & $50(89.3)$ & $1(1.8)$ \\
Depression & $14(25.0)$ & $41(73.2)$ & $1(1.8)$ \\
Schizophrenia & $5(8.9)$ & $50(89.3)$ & $1(1.8)$ \\
Bipolar disorder & $5(8.9)$ & $50(89.3)$ & $1(1.8)$ \\
Other - ADHD & $1(1.8)$ & - & - \\
Other - BPD & $1(1.8)$ & - & - \\
Other - delusional/ & $1(1.8)$ & - & \\
hallucinations & $1(1.8)$ & - & - \\
$\begin{array}{l}\text { Other - seizures } \\
\text { Other - psychosis }\end{array}$ & $1(1.8)$ & - & - \\
(one week) & $20(35.7)$ & - & - \\
Other - None & & & \\
\hline
\end{tabular}

Given the aforementioned background of participants in treatment for problems related to substance use and abuse, it was found that within the sample $10.7 \%$ of the patients were categorized to have very severe psychological distress and $32.1 \%$ categorized with severe psychological distress, thus suggesting that both groups are likely to have a depressive or anxiety disorder. This result while minuscule in its representation of the wider Jamaican population is somewhat reflective of multiple national population studies conducted since the 1980's that show that individuals diagnosed with a mood or anxiety disorder were about twice as likely to suffer also from a drug use disorder in contrast to general populations. ${ }^{24}$ Additionally $26.8 \%$ were categorized as having moderate psychological distress and $30.4 \%$ categorized as having low psychological distress, thus were likely to be well. Of 15 patients who were categorized as having moderate psychological distress, 93.3\% were male and $6.7 \%$ female. Likewise, of 18 participants categorized as having severe psychological distress, $77.8 \%$ were male and $22.2 \%$ female, with 
patients categorized as having severe psychological distress $(n=6), 83.3 \%$ were male and $16.7 \%$ female. These results are consistent with findings worldwide of drug use disorders and co-morbid conditions being more prevalent among males in comparison to their female counterparts. ${ }^{5,23-24}$

\section{Perceived family functionality and psychological distress}

Measure of perceived family functionality among this sample indicated that $66.1 \%$ have high perceived family functioning, $16.1 \%$ perceive moderate family dysfunction and $17.9 \%$ perceive severe family dysfunction. Cross-tabulation of measures of perceived family functioning and psychological distress indicate that seven patients who perceive severe family dysfunction have severe to very severe psychological distress; five patients who perceive moderate family dysfunction have severe to very severe psychological distress; and twelve patients who perceive little or no family dysfunction, thus high family functioning have severe to very severe psychological distress. The variations in the result would suggest that a larger sample is needed for greater analysis which may serve to reflect more accurate variations. However, it is noted that social support has been studied in relation to drug abuse and dependence, where research suggested that stressful life events have a powerful effect in determining individual outcomes more so than treatment. ${ }^{25}$ Moreover, given that within treatment centre programmes, a part of the rehabilitation process is assisting patients in improving family relationships and personal outcomes and also fostering social inclusion. ${ }^{25-26}$ Therefore, it is of vital importance to have an understanding of perceived family function by patients in order to study psychosocial issues that may contribute to the patients' problems. $^{27}$

\section{Treatment received in Centres for substance use disorders and satisfaction with treatment}

Treatment types included predominantly counselling $(83.9 \%)$, group therapy $(7.9 \%)$, support group $(60.7 \%)$, self help $(51.8 \%)$, meditation $(44.6 \%)$, medication $(37.5 \%)$, psychotherapy $(35.7 \%)$ and other types of treatment accounting for $(19.8 \%)$ (i.e. exercise and sports, biblical study, Christian inspiration, and breathing exercises). Patients' satisfaction with their treatment was $83.9 \%$, not satisfied $5.4 \%$, and undecided $8.9 \%$. Treatment definition is the application of any specialist inter- vention that aims to have a beneficial impact upon behavior and welfare of a problem drug user. ${ }^{26}$

This definition speaks to an array of interventions that focus on objectives for safer drug use, stabilization of behaviors and abstinence worldwide and by extension Jamaica. Hence, multiple modalities used for treatment have been dependent on the drug of abuse as well as severity of the symptoms. The predominant exposure to and use of "talking therapies" which includes counselling, group therapy, and psychotherapy have been found to be effective in reducing substance use problems and crime involvement. ${ }^{25-26}$

Furthermore, attendance to individual and group counselling in a drug-free environment was related to a lower risk of relapse. ${ }^{28}$ Studies conducted in the United States and United Kingdom have also found these approaches to be effective in reducing harm associated with substance use dependence. ${ }^{26}$ The use of support groups, thus self-help have been found to have better outcomes post-treatment ${ }^{29}$ as well as in aiding individuals who meet for supporting one another in their fight to abstain live more productive and fulfilling lives. ${ }^{25}$ Moreover, the use of pharmacotherapies have been found to be effective in the detoxification process ${ }^{26}$ prior to rehabilitation ${ }^{25}$, which is the general process of some facilities. Given the track thus far of the treatment centres and their treatment offerings, one can estimate that recovery for those exposed to multiple modalities within the "talking therapies" and otherwise may have better outcomes for drug abstinence.

Review of qualitative responses has given further insight into the areas of satisfaction and dissatisfaction for patients receiving treatment for substance use and abuse. Recurrent themes pertaining to satisfaction, thus 'likes' are related to that of: 1) staff treatment of clients; 2) the treatment modalities offered by the treatment centres; 3 ) the structure of the treatment programme and management of the facilities to promote a protective environment, and 4) the focus of treatment centres which supports client accountability and understanding intra and interpersonal dynamics. On the other hand, recurrent themes pertaining to dissatisfaction, therefore 'dislikes' are related to that of 1) Unnecessary and inflexible rules; 2) side effects of medications received; 3 ) misconduct and disrespect from other patients; 4) staff compliment to programme; 5) issues of privacy and accountability; and 6) inadequate food portions and preparation. Given the areas of satisfaction 
and dissatisfaction, patients $(n=20)$ provided suggestions for 'change' for the various treatment programmes. The recurring themes presented in relation to areas of change included: 1) need for more group therapy and AA/NA meetings to attend;2) food portions and accessibility;3) need for more activities - recreational and skills training; 4) inflexible rules; 5) the effectiveness of medications for treatment and their side effects; 6) the quantity of staff and the quality of the staff-patient interaction; and 7) the need for programme funding for the facilities treating substance use and abuse problems. In light of the above mentioned qualitative results, of particular note is that many studies have made the connection between positive counsellor-patient relationships and 'matching' patients and treatments to better rehabilitation and relapse prevention outcomes. ${ }^{25}$ Taking satisfaction of the treatment into consideration, if patients are consistently satisfied, this has ramifications for the success of treatment, as patients may be more motivated to stay in the programmes for the duration of their respective treatment plans. ${ }^{30}$

\section{CONCLUSION}

The presence of very severe and severe psychological distress among patients being treated for substance abuse, in the population sampled suggests that patients captured in both groups are likely to have a Depressive or Anxiety disorder. This in turn has implications for client treatment and rehabilitation. The perception of family functionality among patients with psychological distress was varied. This variation of patients presenting with severe to very severe psychological distress perceiving moderate to severe family dysfunction has implications for the therapeutic process, as the research suggests that familial support and healthy family functioning serves as a factor for promoting individuals well-being and better treatment outcomes, ${ }^{31-32}$ which may also have an influence the outcomes of treatment for those in the treatment centres. Finally, predominant exposure to and use of multiple modalities with particular focus on "talking therapies" which includes counselling, group therapy and psychotherapy are an effective approach in reducing substance use problems and reduces the risk of relapse.

These outcomes are further enhanced if clients are satisfied with the treatment received and the partnerships had with helping professionals in the recovery process. In light of the above, despite the small sample size which does not allow for generalizability, the results do highlight that the phenomena explored is of importance and that further research in this area with a larger sample may afford helping professionals and therapeutic communities further insight so as to tailor treatment and rehabilitation programmes and policies accordingly.

\section{Limitations}

The main limitation of this study was the small sample size for the purpose of analysis. However, the limited sample for this project was unavoidable due to the low client intake in the various facilities during the specified period of data collection, closure of some treatment facilities, and due to minimal volunteering participants despite the varied recruiting strategies exhausted. A further impediment which led to the small sample size was due to ineligibility of some respondents based on the inclusion and exclusion criteria set. Lastly, an additional limitation of this study was limited resources that placed constraints on accessing areas of the island which could have facilitated gaining additional participants for the research.

\section{Recommendations}

In light of the results obtained and limitations highlighted in this study, the following recommendations should be considered for future exploration of the phenomenon. To this end, should future research be feasible, research methodologies which foster the use of pre and post testing with the use of the various interventions and or a longitudinal approach could be employed rather than a cross-sectional design. In doing so, this may serve to present an accurate and possibly more detailed depiction of psychological distress experienced and the experience of patients in treatment for substance use and abuse in Jamaica.

Results obtained from either or both approaches may shed light on treatment modalities used and their effectiveness, which may have an impact on policy and effectively promote changes in treatment centres across the island. Overall, the results indicate the need for continued data collection across the island of Jamaica for a prolonged period of time in light of periods of low intake in treatment centres so as to enhance the quality of the data. Additionally, more convincing studies that speak to treatment planning, design and policy implications have been those that follow patients upon intake into treatment centres and trace changes throughout and after treatment. 
Other studies with similar strengths are those experimental in nature or have involved random assignment of patients to specific interventions and comparison conditions. ${ }^{25}$ Such studies may then serve to be more supportive to imply changes to policy and programme designs.

\section{ACKNOWLEDGEMENTS}

Special thanks to the Government of Canada/DFAIT, Organization of America States (OAS), Inter-American Drug Control Commission (CICAD), Centre for Addiction and Mental Health (CAMH - Toronto/Canada), University of the West Indies, Mona, The National Council on Drug Abuse (NCDA), the collaborators and more importantly, the clients who made the time to participate in the study.

\section{REFERENCES}

1. Central Intelligence Agency [online]. The world fact book: Jamaica. 2009 [access 2009 Jun 22] Available at: www.cia.gov/library/publications/the-worldfactbook/geos/JM.html

2. National Council on Drug Abuse. National household survey of drug use and abuse in Jamaica. Jamaica: National Council on Drug Abuse; 2001.

3. Organización de los Estados Americanos, Comisión Interamericana para el Control del Abuso de Drogas. Jamaica: Evaluación del Progreso de Control de Drogas, 2005-2006. Mecanismo de Evaluación Multilateral. Washington D.C. (US): OEA, CICAD; 2006.

4. Organización de los Estados Americanos, Comisión Interamericana para el Control del Abuso de Drogas. Jamaica: Evaluación del Progreso de Control de Drogas, 2007-2009. Mecanismo de Evaluación Multilateral. Washington D.C. (US): OEA, CICAD; 2010

5. The National Council on Drug Abuse. NCDA/ EPI-SIDUC Summary 2004-2008. Jamaica: National Council on Drug Abuse; 2008.

6. Irons-Morgan, M. (1999). Suicide rate in Jamaica in 1998 and the prevalence of mental disorders and stressful life events in suicide victims in Kingston, St. Andrew and St. Catherine in 1998 [tesis online]. Kingston (JM): University of the West Indies, Department of Community Health and Psychiatry; 1999 [access 2010 May 18] Available at: http://bases.bireme.br/cgi-bin/wxislind.exe/iah/ online/?isisScript

7. Lowe G, Gibson RC. Depression in adolescence: new developments. West Indian Med J. 2005 Dec; 54(6):387-91.

8. Hickling FW, Abel WD, Gibson R. Depression: A major public health problem facing the Caribbean. West Indian Med J. 2005 Dec; 54(6):353-4.
9. De La Haye W. Dual diagnosis [online]. 2006 [access 2009 Jun]. Available at: http:/ / www.cicad.oas.org/ reduccion_demanda/esp/pp-eng.pdf

10. Barnaby L, Gibson RC. (2008). Factors affecting completion of a 28-day inpatient subtance abuse treatment programme at the University Hospital of the West Indies. West Indian Med J. 2008 Sep; 57(4):364-8.

11. Skinner WJW, Grady CP, Bartha C, Parker C. Concurrent substance use and mental health disorders: an information guide. Toronto (CA):. CAMH Publications; 2004.

12. Watkins TR, Lewellen A, Barret M. Issues and problems with dual diagnosis. In: Dual diagnosis: an integrated approach to treatment. Thousand Oak: Sage Publications; 2001. p. 11-24.

13. Kessler RC, Andrews G, Colpe LJ, Hiripi E, Mroczek DK, Normand SLT, et al. Short screening scales to monitor population prevalances and trends in nonspecific psychological distress. Psychol Medicine. 2002 Aug; 32(6):959-76.

14. Hersh DF, Modesto-Lowe V. Drug abuse and mood disorders.In: Henry BK, Bruce J, Rounsaville MD, editors. Dual diagnosis and treatment. New York (US); Marcel Dekker, Inc. ;1998. p. 177-201.

15. Kranzler HR, Mason B, Modesto-Lowe V. Prevalence, diagnosis, and treatment of comorbid mood disorders and alcoholism. In: Kranzler HR, Rounsaville B, editors. Dual diagnosis and treatment. New York (US): Marcel Dekker, Inc. 1998. p. 107-36.

16. Kessler RC, Nelson CB, McGonagle KA, Edlund MJ, Frank RG, Leaf PJ. The epidemiology of co-occurring addictive and mental disorders: implications for prevention and service utilization. Am J Orthopsychiatry. 1996 Jan; 66(1):17-31.

17. Smilkstein G. The family APGAR: a proposal for family function test and its use by physicians. J Fam Prac.1978 Jun; 6(6):1231-9.

18. McBride CM, Curry SJ, Stephens RS, Wells EA, Roffman RA, Hawkins J.D. Intrinsic and extrinsic motivation for change in cigarette smokers, marijuana smokers, and cocaine users. Psychol Addic Behaviors. 1994, 8(4):243-50.

19. Ryan RM, Plant RW, O'Malley S. Initial motivations for alcohol treatment: relations with patient characteristics, treatment involvement, and dropout. Addict Behav. 1995 May-Jun; 20(3):279-97.

20. Joe, G.W., Simpson, D., and Broome, K.M. Effects of readiness for drug abuse treatment on client retention and assessment process. Addiction. 1998 Aug; 93(8):1177-90.

21. DiClemente CC, Bellino LE, Neavins TM. Motivation for change and alcoholism treatment. Alcohol Res Health. 1999; 23(2):86-92.

22. Carpenter KM, Miele GM, Hasin DS. Does motivation to change mediate the effect of DSM-IV substance 
use disorders on treatment utilization and substance use? Addict Behav. 2002 Mar-Apr; 27(2):207-25.

23. National Institute on Drug Abuse. Trends in drug abuse [online]. USA: National Institute of Health, U.S. Department of Health and Human Services; 2007 [access 2009 Jun 25] Available at: http:/ / www.nida. nih.gov/about/welcome/aboutdrugabuse/trends/

24. National Institute on Drug Abuse. Comorbidity: addiction and other mental illness. USA: National Institute of Health, U.S. Department of Health and Human Services; 2008.

25. United Nations. Contemporary drug abuse treatment: a review of the evidence base. New York (US): United Nations Office on Drugs and Crime; 2002.

26. Stevens A, Hallam C, Trace M. Report 10. Treatent for dependent drug use: a guide for policymakers. The Beckley Foundation Drug Policy Programme; 2006.

27. Smilstein G. The cycle of the family function: a conceptual model for family medicine. J Fam Pract. 1980 Aug; 11(2):223-32.

28. Fiorentine R, Anglin D. Does increasing the opportunity for counselling increase the effectiveness of outpatient drug treatment? Am J Drug Alcohol Abuse. 1997 Aug; 23(3):369-82.

29. McKay JR, Alterman AI, Cacciola JS, Rutherford MJ, O'Brien CP, Koppenhaver J. Group conselling vs. individualized relapse prevention aftercare following intensive outpatient treatment for cocaine dependence: initial results. J Consult Clin Psychol. 1997 Oct; 65(5):778-88.

30. Simpson DD, Joe GW, Brown BS. Treatment retention and follow-up outcomes in the drug abuse treatment outcome study (DATOS). Psychol Addict Behav, 1997; 11:239-60.

31. Murray-Swank A, Glynn S, Cohen AN, Sherman M, Medoff DP, Fang LJ, et al. Family contact, experience of family relationships, and views about family involvement in treatment among VA consumers with serious mental illness. J Rehabil Res Dev. 2007; 44(6):801-11.

32. Dakof GA, Tejeda M, Liddle HA. Predictors of engagement in adolescent drug abuse treatment. J Am Acad Child Adolesc Psychiatry. 2001 Mar; 40(3):274-81. 